\author{
М. О. Леонтьева \\ Уральский федеральный университет \\ Екатеринбург, Россия \\ marileonteva@yandex.ru
}

\title{
Пейоративные обозначения глаз \\ в русских народных говорах: семантико-мотивационный аспект
}

В говорах Вологодской и Костромской области обнаруживаются многочисленные пейоративные обозначения органа зрительной перцепции, при этом наиболее активно номинируются вытаращенные глаза. Экспрессивные номинации, реализующие данную идеограмму, выступают в однотипных, регулярно воспроизводимых контекстах: влг. «Пу́лыши чего выкатила?», «Чего выпалила ла́ндыши-то?».

В мотивационном отношении типичными являются лексемы, связанные с глаголами со значением 'глядеть, смотреть': диал. шир. распр. гляде́лки, гляде́льц̧а, костр. зо́рьки. Акцент в данном случае делается на гипертрофированно воспринимаемой функции зрения.

С другой стороны, в основу большого количества лексем может быть положен признак увеличения, выпуклости, который выражается на базе производящих основ разного типа.

Во-первых, выпуклость может быть отражена путем метафоризации на базе слов, обозначающих округлые предметы. Глаза сравниваются с округлыми наростами на дереве (влг. ба́кльl 'вытаращенные глаза' < бакла́ 'нарост на дереве'), с плодами растений (костр. лу́ковицьл, ср. литер. глазные яблоки). Сопоставление с округлыми предметами встречаем также в прост. шары 'глаза', глаза как блюдца. В описанную модель встраивается этимология слова глаз, у которого развивается значение 'орган зрения' от первоначального 'небольшой камень, булыжник’ [Аникин, 10, 271].

Во-вторых, глаза человека могут сравниваться с глазами некоторых животных, которые воспринимаются как большие или выпуклые. Сравнение с глазами коровы (как у коровы (глаза), коровьи глаза) распространены достаточно широко. Интереснее дериваты на основе слова

(C) Леонтьева М. О., 2019 
рак, которое мотивирует влг. páчúmь (кра́чить) ‘таращить глаза’; от них, в свою очередь, производны влг. ра́чки́ и кра́чки 'вытаращенные глаза'.

В-третьих, признак выпуклости может передаваться через трансляцию идеи «разбухания», увеличения. Влг, костр. бу́лыши, костр. пýлылши восходят к праслав. *bula 'нечто округлое, шишка, нарост' [Аникин, 5, 122, 123]. Идея увеличения также «прочитывается» в костр. пу́чеги, ср. выпучить (ся), и костр. лу́пь, ср. вылупить(ся).

Рассматриваемое Е. Л. Березович костр. берестянь́lе глаза́ 'глаза бессовестного или наглого человека' представляет собой случай комплексной мотивации. Из компонента берестяной выводятся признаки белого цвета и древесной коры. С одной стороны, акцент делается на белом цвете - устойчивой негативной характеристике глаз, ср. также костр. бельши' ‘вытаращенные глаза' < бель́ш 'белок глаза'. С другой стороны, глазам приписывается «деревянность», они сравниваются с тупым, непроницаемым материалом, передающим идею бесчувственности, ср. еще костр. лубянь́е глаза́ 'пустые, не выражающие эмоций глаза' [Березович, 2016, 71-74].

Помимо «деревянности», глазам приписывается также связь со стеклом (глаза как блюдияа), с камнем (ср. этимологию слова глаз) и с металлом (глаза по пять рублей). Таким образом, наблюдается тенденция к сравнению органа зрения с простым, грубым материалом. Сравнение такого рода может быть совмещено с признаком округлой формы.

Некоторые названия вытаращенных глаз требуют этимологической реконструкции. В качестве примера рассмотрим пенз., ср.-урал. máль́l и вят., киров., перм., нижегор., юж., яросл., костр. то́ль́l, которые, возможно, связаны с тальй и таять [Фасмер, 4, 16], но семантическая сторона этой реконструкции пока неясна.

Слова из гнезда с основой тал- называют водные участки природного пространства: литер. проталина, костр. та́лища 'проталина', арх., олон. тало́ 'оттаявшее место', свердл. та́ль 'талая вода' и др. Семантика приведенных слов выводит к идее сопоставления глаз с водными источниками. Перенос 'глаза' > 'водные образования' частотен в народной географической терминологии: ср. арх. глазови́на 'лужа на болоте', польск. диал. oko 'незаросшая, голая часть на водной поверхности’ и др. [Журавлев, 2005, 332-333]. Вода и глаза имеют общие свойства: зеркальное отражение объектов окружающего мира, 
связанный с отражением света блеск, прозрачность воды (корреляция со зрением) и, наконец, сам по себе водный состав (глаза воспринимаются как жидкость) [Ясинская, 2015, 49-50]. На наш взгляд, важен также признак «выделимости» водного участка в окружающем пространстве, подобно тому как специфический по своей структуре орган зрения выделяется на кожной поверхности.

Предположительно, мотивирующим для рассматриваемого máл ́́l‘ глаза' мог послужить диалектный географический термин с корнем тал-, обозначающий какое-то водное пространство. Перенос такого рода обеспечивает комплексную мотивацию, которая базируется на целом ряде признаков. Актуализируется не только сравнение с водной гладью (с присущими ей свойствами, которые ассоциируются со свойствами глаз), но также характерные для талых мест (по сравнению с другими водными источниками) специфические признаки. К ним относится, во-первых, признак таяния, который может ассоциироваться со слезами, и, во-вторых, признак холода (источником талых мест являются снег и лед). Е. Л. Березович отмечает значимость этого признака в названиях глаз: «Слова, отсылающие к образам мороза и льда, могут выражать не только “физические” признаки глаз, но и психоэмоциональные и поведенческие характеристики их носителей, ср. ср.-урал. моро́женый 'светло-серый (о глазах)', выражения ледяной взгляд, ледяные глаза, перм. глаза́ заморо́жены 'о бессовестном, наглом человеке'» [Березович, 2016, 66]. Признак холода, «замороженности» мог сыграть значительную роль для появления номинации máль́l, учитывая ее негативную экспрессию.

Аникин A. E. Русский этимологический словарь. М., 2007-. Вып. 1-.

Березович Е. Л. Берестяная рожа и берестяные глаза: Этнолингвистический комментарий к русским диалектным фразеологизмам // Slavische Geisteskultur: Ethnolinguistische und philologische Forschungen. T. 1 / Hrsg. A. A. Alekseev. Frankfurt am Main, 2016. S. 57-81.

Журавлев А. Ф. Язык и миф. Лингвистический комментарий к труду А. Н. Афанасьева «Поэтические воззрения славян на природу». М., 2005.

Фасмер М. Этимологический словарь русского языка : в 4 т. / пер. с нем. и доп. О. Н. Трубачева. М., 1986-1987.

Ясинская М. В. Представления о глазах и зрении в языке и традиционной культуре славян : дис. ... канд. филол. наук / Ин-т славяноведения РАН. М., 2015. 